\title{
In vitro antioxidant capacity and free radical scavenging evaluation of active metabolite constituents of Newbouldia laevis ethanolic leaf extract
}

\author{
Josiah Bitrus Habu' and Bartholomew Okechukwu Ibeh $2,3^{*}$
}

\begin{abstract}
Background: The aim of the present study was to evaluate the in vitro antioxidant and free radical scavenging capacity of bioactive metabolites present in Newbouldia laevis leaf extract.

Results: Chromatographic and spectrophotometric methods were used in the study and modified where necessary in the study. Bioactivity of the extract was determined at $10 \mu \mathrm{g} / \mathrm{ml}, 50 \mu \mathrm{g} / \mathrm{ml}, 100 \mu \mathrm{g} / \mathrm{ml}, 200 \mu \mathrm{g} / \mathrm{ml}$ and $400 \mu \mathrm{g} / \mathrm{ml}$ concentrations expressed in \% inhibition. The yield of the ethanolic leaf extract of N.laevis was $30.3 \mathrm{~g}$ (9.93\%). Evaluation of bioactive metabolic constituents gave high levels of ascorbic acid (515.53 $\pm 12 \mathrm{lU} / 100 \mathrm{~g}[25.7 \mathrm{mg} / 100 \mathrm{~g}]$ ), vitamin $\mathrm{E}$ (26.46 $\pm 1.08 \mathrm{IU} / 100 \mathrm{~g})$, saponins (6.2 \pm 0.10$)$, alkaloids ( $2.20 \pm 0.03)$, cardiac glycosides $(1.48 \pm 0.22)$, amino acids and steroids (8.01 \pm 0.04$)$ measured in $\mathrm{mg} / 100 \mathrm{~g}$ dry weight; moderate levels of vitamin A (188.28 $\pm 6.19 \mathrm{lU} / 100 \mathrm{~g})$, tannins ( $0.09 \pm 0.30)$, terpenoids ( $3.42 \pm 0.67)$; low level of flavonoids $(1.01 \pm 0.34 \mathrm{mg} / 100 \mathrm{~g})$ and absence of cyanogenic glycosides, carboxylic acids and aldehydes/ketones. The extracts percentage inhibition of DPPH, hydroxyl radical $(\mathrm{OH})$ ), superoxide anion $\left(\mathrm{O}_{2}{ }^{-}\right)$, iron chelating, nitric oxide radical $(\mathrm{NO})$, peroxynitrite $\left(\mathrm{ONOO}^{-}\right)$, singlet oxygen $\left({ }^{1} \mathrm{O}_{2}\right)$, hypochlorous acid $(\mathrm{HOCl})$, lipid peroxidation (LPO) and FRAP showed a concentration-dependent antioxidant activity with no significant difference with the controls. Though, $\mathrm{IC}_{50}$ of the extract showed significant difference only in singlet oxygen $\left({ }^{1} \mathrm{O}_{2}\right)$ and iron chelating activity when compared with the controls.
\end{abstract}

Conclusions: The extract is a potential source of antioxidants/free radical scavengers having important metabolites which maybe linked to its ethno-medicinal use.

Keywords: Newbouldia laevis, Phytochemicals, Ethanolic extraction, Antioxidants, Free radical scavengers, Bioactive constituents

\section{Background}

The African continent has one of the richest biodiversity in the world and abounds in plants of economic and medicinal importance which when developed would reduce expenditure on global drug development while meeting patient's health needs [1]. Current emphasis on healthy living based on antioxidant intake and the implication of oxidative stress molecules/free radicals on certain diseased condition [2] has generated renewed interest in

\footnotetext{
* Correspondence: barthokeyibeh@yahoo.com

${ }^{2}$ Department of Biochemistry, College of Natural and Applied Sciences, Michael Okpara University of Agriculture Umudike, Umudike, Nigeria

${ }^{3}$ National Biotechnology Development Agency, Abuja, Nigeria

Full list of author information is available at the end of the article
}

screening for plants with high antioxidative properties. The identification and quantification of bioactive components that contribute to free radical scavenging activity and its consequent ethnopharmcological effect may provide link to specific drug discovery.

Newbouldia laevis is commonly known as African border tree. In Nigerian major languages it is called 'Aduruku' in Hausa, Ogirisi' in Igbo and Akoko in Yoruba [3]. N. laevis is a medium sized, sun loving, fast growing drought tolerant angiosperm which belongs to the Bignoniaceae family [4]. It grows up to a height of about 7-15 meters but is usually a shrub of 2-3 meters with many stemmed forming clumps of gnarled branches. In 
sub-Saharan Africa, the plant is used in the management of a variety of ailments for example, the bark is chewed and swallowed for stomach pains and diarrhoea as well as toothache [5]. In Nigeria and Ivory Coast, the stem bark decoctions are used for treatment of epilepsy and convulsions in children [6]. Similarly, Senegalese use the stem bark for the treatment of rheumatism especially painful arthritis of the knee. The plant also has medicinal therapy against ear aches, sore feet and chest pain [7]. Currently, leaf and root extracts of $N$. laevis have been shown to possess antimalaria $[8,9]$ and antimicrobial activities $[10,11]$. The leaves, stem and fruits have been used for febrifuge, wound dressing and stomach ache medication [12].

No extensive report on the presence, and free radical scavenging activity of basic metabolites from the leaves of $N$. laevis has been provided. Similarly, investigations of the plant have produced conflicting reports on the content of phytochemical compounds present in the plant leaf thus provide scarce and inaccurate information. Furthermore, the antioxidative potential of the plant leaf have not been critically evaluated. The study therefore, evaluated the principal metabolites present in the ethanolic leaf extract of the plant as well as the antioxidant potential and free radical scavenging activity of the leaf extract. The extract was examined for different reactive oxygen species (ROS) scavenging activities including hydroxyl, superoxide, nitric oxide, hydrogen peroxide, peroxynitrite, singlet oxygen and hypochlorous acid, iron chelating capacity, antioxidant activity and metabolic constituents.

\section{Results}

Extractive yield

The yield of the ethanolic leaf extract of $N$. laevis was $30.3 \mathrm{~g}(9.93 \%)$.

\section{Phytochemical analysis}

Preliminary phytochemical screening of N.laevis shows the presence of alkaloids, saponins, tannins, cardiac and steroidal glycosides, flavonoids, other metabolites were amino acids (Table 1) and vitamins A,C and E (Figure 1) while carboxylic acids, anthracene derivatives and aldehydes were absent. Evaluation of bioactive metabolic constituents gave high levels of saponins $(6.2 \pm 0.10)$, alkaloids $(2.20 \pm 0.03)$, cardiac glycosides $(1.48 \pm 0.22)$, amino acids, steroids $(8.01 \pm 0.04)$; moderate levels of tannins $(0.09 \pm 0.30)$, terpenoids $(3.42 \pm 0.67)$ and low levels of flavonoids $(1.01 \pm 0.34 \mathrm{mg} / 100 \mathrm{~g})$ (Table 2).

\section{Antioxidant vitamin composition found in the leaf extracts of Newbouldia laevis}

The result shown in Figure 1 summarizes the composition of antioxidant vitamins present in the leaves of $N$. laevis grown in Nigeria a sub-Sahara African country.
Table 1 Phytochemical screening of basic metabolites of the leaf extracts of Newbouldia laevis

\begin{tabular}{ll}
\hline Plant metabolite & Extract content \\
\hline Cyanogenic glycosides & + \\
Cardiac glycosides & ++ \\
Steroid glycoside & + \\
Saponins & +++ \\
Tannins & ++ \\
Alkaloids & +++ \\
Amino acids & +++ \\
Terpenoids & ++ \\
Flavonoids & + \\
Carboxylic acids & - \\
Aldehyde/ketones & - \\
Ascorbic acid & +++ \\
Anthracene derivatives & - \\
\hline
\end{tabular}

$+=$ Trace, $++=$ high, $+++=$ Abundant, $-=$ Absent.

Summary of TLC phytochemical identification of $N$. leavis leaf extract.

The concentration of vitamins measured in IU/100 g weight shows moderate levels of Vitamin A (188.28 \pm 6.19$)$ and high levels of vitamins C (515.53 $\pm 12[25.7 \mathrm{mg} / 100 \mathrm{~g}])$ and $\mathrm{E}(26.46 \pm 1.08)$.

\section{Antioxidant and free radical scavenging activity}

The percentage inhibition of hydroxyl radical $\left(\mathrm{OH}^{-}\right)$and mannitol standard, superoxide anion $\left(\mathrm{O}_{2}{ }^{-}\right)$/quercetin, iron chelating /EDTA, and, nitric oxide radical (NO)/curcumin, peroxynitrite $\left(\mathrm{ONOO}^{-}\right)$/gallic acid, singlet oxygen $\left({ }^{1} \mathrm{O}_{2}\right) /$ lipoic acid, hypochlorous acid (HOCl)/ascorbic acid, $\mathrm{DPPH} /$ ascorbic acid, inhibition of lipid peroxidation (LPO) measured as TBARS and FRAP (Table 3) by $N$. laevis leaf extract showed a significant $(\mathrm{P}<0.05)$ concentration-dependent antioxidant activity. The leaf extract had a comparable reduction capacity in all the concentrations measured when compared with the scavenging activity of known standards. The $\mathrm{IC}_{50}$ values of the extract showed significant difference only in singlet oxygen $\left({ }^{1} \mathrm{O}_{2}\right) \quad(510.65 \pm 9.54)$ vs lipoic acid standard $(46.15 \pm 1.16)$ and iron chelating $(1225.05 \pm 298.1)$ vs EDTA standard $(1.27 \pm 0.05)$ (Table 4$)$. The FRAP of the extract at $400 \mu \mathrm{g} / \mathrm{ml}$ was $64 \pm 2.52 \%$ (FRAP: 0.64 ) (Table 3) and that of the inhibition of lipid peroxidation (LPO) was $91.85 \pm 0.34 \%$ (Table 3). The extract showed a good reducing power in a concentration dependent manner.

\section{Discussion}

The investigation reported here reveals the presence of secondary metabolites such as alkaloids, tannins, flavonoids and cardiac glycosides in the ethanolic leaf extract of $N$. laevis and the free radical scavenging activity 


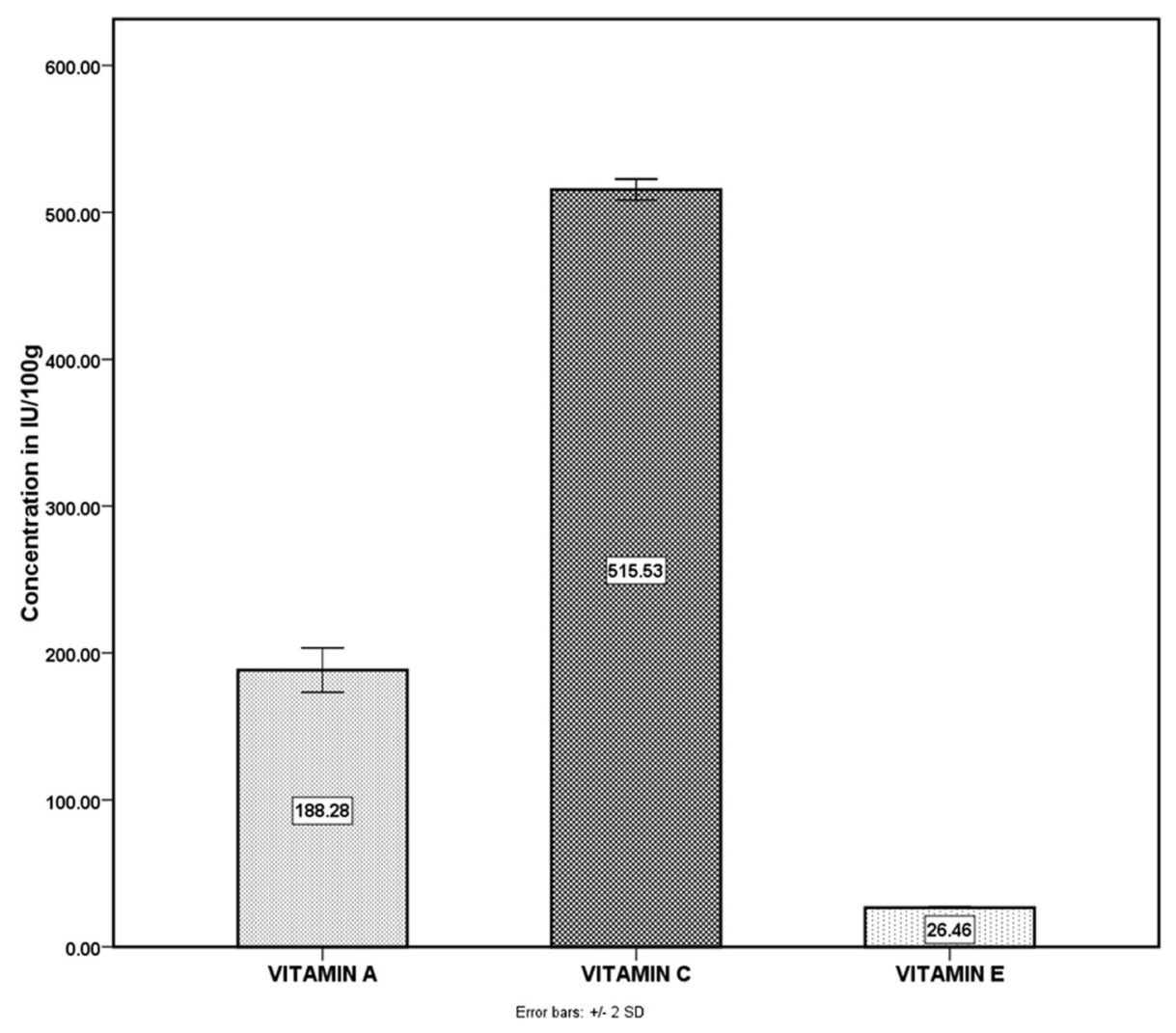

Figure 1 Antioxidant vitamin composition found in the leaf extracts of Newbouldia laevis Data are represented as mean $(n=6)$.

inherent in the plant species. The high antioxidant activity may relate to the plants' curative and/or management potential of many ailments claimed in its ethnomedicine. Earlier studies on the leaf and bark extracts of the Congolese $N$. leavis showed the absence of flavonoids, saponins, quinones, terpenes and steroids [13]. Although, recent phytochemical studies on the root, bark and stem of the plant have revealed the presence of alkaloid, quinoid and phenylpropanoid compounds [14].

Table 2 Phytochemical composition of metabolites found in the leave extracts of Newbouldia laevis (mg/100 $\mathrm{g}$ dry weight)

\begin{tabular}{ll}
\hline Plant metabolite & Composition \\
\hline Cardiac glycosides & $1.48 \pm 0.22$ \\
Saponins & $6.2 \pm 0.10$ \\
Tannins & $0.09 \pm 0.30$ \\
Alkaloids & $2.20 \pm 0.03$ \\
Flavonoids & $1.01 \pm 0.34$ \\
Steroids & $8.01 \pm 0.04$ \\
Terpenoids & $3.42 \pm 0.67$ \\
\hline
\end{tabular}

Results are mean of sextuplicate determinations on a dry weight basis \pm standard deviation.
Phytochemical results showed the absence of carboxylic acids, aldehyde/ketones and anthracene derivatives in the ethanolic leaf extract. However, the biological active components present in the extract were vitamins $\mathrm{A}, \mathrm{C}$ and $\mathrm{E}$, tannins, saponins, cardiac glycosides, flavonoids, alkaloids, steroids and terpenoids, this was corroborated by previous works on phytochemicals of $N$. laevis [15]. The discordant results from several other authors $[13,16]$ on the bioactive metabolites (especially absence of saponins) present in $N$. laevis maybe as a result of the medium of extraction (i.e. solvent), storage and environmental factors. High levels of amino acids, saponins $(6.2 \pm 0.10)$, steroids $(8.01 \pm 0.04)$, alkaloids $(2.20 \pm 0.03)$ and terpenoids $(3.42 \pm 0.67)$ characterized $N$. laevis leaf extract. The phytochemicals identified have been shown to have curative effect on several disease pathogens, thus may relate to $N$. laevis widely ethno-medicinal use $[9,11]$. Saponins for instance have the ability to bind sterols of cell membrane and reduce choleasterol levels hence are widely used in conventional medicines exhibiting hypocholeasterolemic effects. Generally, it could be recalled that saponins form foams in aqueous solution which have haemolytic activity and choleasterol binding properties. They have natural tendency to ward-off microbes which makes them good candidates for treating fungal and yeast infections. These compounds served as 
Table 3 Free radical scavenging potential of Newbouldia laevis measured as $\%$ inhibition

\begin{tabular}{|c|c|c|c|c|c|c|c|c|c|c|}
\hline \multicolumn{11}{|c|}{ Antioxidant activity (\% Inhibition ) } \\
\hline $\begin{array}{l}\text { Conc } \\
(\mu g / m l)\end{array}$ & $\begin{array}{l}\text { Hydroxyl } \\
\text { radical }\left(\mathrm{OH}^{\prime}\right)\end{array}$ & $\begin{array}{l}\text { Superoxide } \\
\text { anion }\left(\mathrm{O}_{2} \cdot\right)\end{array}$ & Iron chelating & $\begin{array}{l}\text { Nitric oxide } \\
\text { radical (NO) }\end{array}$ & $\begin{array}{l}\text { Peroxynitrite } \\
\left(\mathrm{ONOO}^{-}\right)\end{array}$ & $\begin{array}{l}\text { Singlet } \\
\text { oxygen }\left({ }^{1} \mathrm{O}_{2}\right)\end{array}$ & $\begin{array}{l}\text { Hypochlorous } \\
\text { acid (HOCl) }\end{array}$ & DPPH & $\begin{array}{l}\text { Lipid peroxidation } \\
\text { (LPO) }\end{array}$ & FRAP (mM) \\
\hline 10 & $25.80 \pm 0.03^{\mathrm{a}}$ & $30.60 \pm 0.05^{\mathrm{a}}$ & $40.10 \pm 0.02^{\mathrm{a}}$ & $41.06 \pm 0.04^{a}$ & $15.60 \pm 0.01^{a}$ & $53.64 \pm 0.72^{\mathrm{a}}$ & $09.60 \pm 0.12^{a}$ & $42.64 \pm 1.12^{a}$ & $53.64 \pm 0.82^{a}$ & $08.07 \pm 0.31^{a}$ \\
\hline 50 & $28.85 \pm 0.01^{\mathrm{a}}$ & $40.65 \pm 0.04^{b}$ & $46.58 \pm 0.04^{\mathrm{a}}$ & $49.75 \pm 0.08^{b}$ & $25.85 \pm 0.04^{b}$ & $59.10 \pm 0.09^{\mathrm{a}}$ & $25.85 \pm 0.31^{b}$ & $45.85 \pm 0.10^{\mathrm{a}}$ & $65.85 \pm 0.09^{\mathrm{a}} 1$ & $18.10 \pm 0.11^{\mathrm{a}}$ \\
\hline 100 & $50.83 \pm 0.11^{\mathrm{b}}$ & $62.74 \pm 0.12^{c}$ & $65.38 \pm 0.07^{\mathrm{b}}$ & $55.13 \pm 0.09^{b}$ & $35.83 \pm 0.09^{c}$ & $71.62 \pm 2.46^{\mathrm{b}}$ & $35.83 \pm 0.05^{c}$ & $65.85 \pm 0.11^{\mathrm{b}}$ & $85.85 \pm 0.14^{b}$ & $30.15 \pm 0.15^{\mathrm{b}}$ \\
\hline 200 & $62.97 \pm 0.04^{c}$ & $69.79 \pm 0.08^{c}$ & $71.67 \pm 0.09^{c}$ & $61.86 \pm 0.07^{c}$ & $48.97 \pm 0.09^{d}$ & $86.16 \pm 1.10^{c}$ & $48.97 \pm 0.09^{d}$ & $79.85 \pm 0.19^{c}$ & $89.85 \pm 0.16^{b}$ & $50.09 \pm 1.20^{c}$ \\
\hline 400 & $76.10 \pm 0.02^{d}$ & $81.11 \pm 0.07^{d}$ & $90.11 \pm 0.08^{d}$ & $80.08 \pm 0.06^{d}$ & $62.10 \pm 0.11^{\mathrm{e}}$ & $96.00 \pm 0.12^{d}$ & $62.10 \pm 0.11^{\mathrm{e}}$ & $85.85 \pm 0.18^{c}$ & $91.85 \pm 0.34^{c}$ & $64.01 \pm 2.52^{\mathrm{d}}$ \\
\hline
\end{tabular}

Data are expressed as mean \pm standard deviation $(n=6)$; mean in the same column with different superscripts are significantly different using Duncan's multiple range test at $p<0.05$. 
Table 4 IC $_{50}$ values of Newbouldia laevis scavenging activity and reference compounds

\begin{tabular}{llll}
\hline Activity & $\mathbf{N}$. Laevis $\mathbf{~ I C}_{\mathbf{5 0}}$ & Reference & $\mathbf{I C}_{\mathbf{5 0}}$ \\
\hline DPPH & $51.4^{\#}$ & Ascorbic acid & $55.4 \pm 20.12^{* *}$ \\
Hydroxyl radical $(\mathrm{OH} \cdot)$ & $497.21 \pm 3.65^{\#}$ & Mannitol & $571.45 \pm 20.12^{* *}$ \\
Nitric oxide radical $(\mathrm{NO})$ & $92.42 \pm 2.73^{\#}$ & Curcumin & $90.82 \pm 4.75(6)^{* *}$ \\
Superoxide anion $\left(\mathrm{O}_{2}{ }^{-}\right)$ & $57.08 \pm 1.22^{\#}$ & Quercetin & $42.06 \pm 1.35^{* *}$ \\
Peroxynitrite $\left(\mathrm{ONOO}{ }^{-}\right)$ & $1210.83 \pm 23.85^{\#}$ & Gallic acid & $876.24 \pm 56.96(6)^{* *}$ \\
Singlet oxygen $\left({ }^{1} \mathrm{O}_{2}\right)$ & $510.65 \pm 9.54$ & Lipoic acid & $46.15 \pm 1.16(6)^{*}$ \\
Hypochlorous acid $(\mathrm{HOCl})$ & $276.04 \pm 12.01^{\#}$ & Ascorbic acid & $235.95 \pm 5.75(6)^{* *}$ \\
Iron Chelating & $1225.05 \pm 298.1$ & EDTA & $1.27 \pm 0.05(6)^{* *}$ \\
\hline
\end{tabular}

Units of $\mathrm{IC}_{50}$ for all activities are $\mu \mathrm{g} / \mathrm{ml}$. Data are expressed as mean \pm S.D.

$\mathrm{EDTA}=$ Ethylenediamine tetraacetic acid. \#indicates no significant difference where ${ }^{*} \mathrm{p}<0.01$ and ${ }^{* *} \mathrm{p}<0.001$.

natural antibiotics that help the body to fight-off infections and microbial invasion and boost the effectiveness of certain vaccines. $N$. laevis inhibits Staphylococcus aureus and Candida albicans growth $[16,17]$, recently the plant have been shown to also stimulate the activity of heapatic glucokinase, inhibiting glucose 6-phosphatase activity [18] thus serving as a good antidiabetic agent. The presence and concentration of these metabolites could explain the use of $N$. laevis in the treatment against various bacterial infections, sexually transmitted diseases and diabetes. The non-sugar part of saponins has a direct antioxidant activity which may contribute to the high free radical scavenging capacity of the plant leaf extract.

The trace level of cyanogenic glycoside could suggest the plant's very low toxicity when ingested in the form of traditional medicine (Table 1). Generally, flavonoids are widely distributed group of polyphenolic compounds, characterized by a common benzopyrone ring structure that has been reported to act as antioxidants in various biological systems. The biological function of flavonoids are extended to include protection against allergies, inflammation, free radicals, platelet aggregation, microbes, ulcers, heapatoxins, viruses and tumours [19]. Germann et. al., [14] revealed the presence of newbouldioside A-C and phenylethanoid glycosides in the stem bark of $N$. laevis.

Quantitative analysis of vitamins A, C and E is indicative of an enhanced free radical scavenging capacity of the plant. The leaf extract could be said to have a moderate vitamin A (188.28 $\pm 6.19 \mathrm{IU} / 100 \mathrm{~g})$, fairly high vitamins $\mathrm{E}$ $(26.46 \pm 1.08 \mathrm{IU} / 100 \mathrm{~g})$ and C $(515.53 \pm 12 \mathrm{IU} / 100 \mathrm{~g})$ content when compared with their respective standard references. However, comparison of the vitamins showed a higher vitamin $\mathrm{C}$ composition. The vitamin constituents of $N$. laevis may establish in part the efficient regulation of reactive oxygen species and scavenging activity observed in the plant extract investigated in addition to maintaining membrane fluidity and integrity. Vitamin $C$ potentially regenerates vitamin $\mathrm{E}$ and renews its potency. A high vitamin $\mathrm{E}$ content of $N$. laevis thus suffices for its antioxidant activity which is responsible for stabilization of biomembrane structure. Vitamin A on the other hand, not only contributes to the plants free radical scavenging activity but also the immunostimulatory property of N. laevis [20].

Phenolic compounds are very important plant constituent with multiple biological functions including antioxidant activity much related to the radical scavenging ability of their $\mathrm{OH}$ groups. A number of studies have reported the relative correlation between phenol and antioxidant activity [21]. It could be seen that alternative solution to synthetic drugs resides in plant natural products mostly those with free radical scavenging property. DPPH has been widely used to evaluate the antioxidant activity of natural products from plant and microbial sources. The result of the present study showed that the in vitro free radical potential of the extract exhibited maximum free radical scavenging activity with a comparable $\mathrm{IC}_{50}$ value of the known standards, except in singlet oxygen quenching and iron chelating property. The antioxidant attributes of $N$. laevis leaf extract as affected by alkaline hydrolysis and the release of bound phenolics have limited experimental evidence with few investigators reporting on stem bark $[22,23]$. The investigated plant metabolites with redox properties plays an important role in absorbing and neutralizing free radicals, quenching singlet and triplet oxygen, or decomposing peroxides as reported in Tables 2, 3 and 4. A higher DPPH radical-scavenging activity is associated with a lower $\mathrm{IC}_{50}$ value thus the results presented here indicates a higher DPPH radicalscavenging activity of the extract though not significant when compared with ascorbic acid standard (Table 4). DPPH is a stable free radical at room temperature and accepts an electron or hydrogen radical to become a stable diamagnetic molecule which is generally regarded to be a model for lipophilic radical activity. The ferric reducing power of the extract at $400 \mu \mathrm{g} / \mathrm{ml}$ gave $64 \pm 2.52 \%$ (FRAP: 0.64 ) and that of inhibition of lipid peroxidation (LPO) was $91.85 \pm 0.34 \%$. The inhibition of TBARS a measure of the oxidative stress was high suggesting that $N$. laevis is a good antioxidant source. As generally observed, the antioxidant reaction of $N$. laevis is concentration-dependent 
which means that an increase in antioxidant activity is linearly dependent on the ethanolic leaf extract concentration of the plant (Table 3).

Hydroxyl radicals are the major active oxygen species causing lipid peroxidation and various biological damage. $N$. laevis extract was able to remove the hydroxyl radicals from the sugar component of the MDA-like oxidant and prevented the oxidative reaction. The $\mathrm{IC}_{50}$ value indicates that the plant extract is a better hydroxyl radical scavenger than the standard mannitol. Similarly, superoxide anion a dangerous radical to cellular components can be removed by the efficient activity of flavonoids which scavenge superoxide anions [24]. As shown in Tables 3 and 4, the superoxide radical scavenging activities of the plant extract and the reference compound quercetin are increased markedly with increasing concentrations and are comparable (no significant difference).

Nitric oxide are important in inflammatory processes but at an increased level are directly toxic to tissues resulting in vascular damage and other ailments. This toxicity is heightened on reaction with superoxide radical to form a second reactive compound peroxynitrite anion $\left(\mathrm{ONOO}^{-}\right)$. $N$. laevis inhibits nitrite formation in the process of generating the radical $(\mathrm{N})$ by direct competition with oxygen. Furthermore, the protonation of peroxynitrite $\left(\mathrm{ONOO}^{-}\right)$ forms a dangerous and highly reactive compound peroxynitrous acid $(\mathrm{ONOOH})$ [25]. The plant extract inhibits the process by scavenging peroxynitrite. $N$. laevis exhibited comparable activity with the two standards curcumin (NO) and gallic acid $\left(\mathrm{ONOO}^{-}\right)$. $\mathrm{HOCl}$ inactivates catalase through breakdown of the heme prosthetic group. The plant extract inhibited catalase indicating its $\mathrm{HOCl}$ scavenging activity. Comparison with the ascorbic acid standard shows no significant difference. Conversely, singlet oxygen which induces hyperoxidation and oxygen cytotoxicity decreases antioxidative activity, also iron chelating effect which can stimulate lipid peroxidation are all reduced in a concentration dependent manner by the extract but not as efficient as the respective standards lipoic acid and EDTA.

\section{Conclusions}

All extracts at tested doses $(10-400 \mu \mathrm{g} \mathrm{mL}-1)$ revealed good scavenging activity for DPPH, FRAP, hydroxyl radical $(\mathrm{OH})$, nitric oxide radical $(\mathrm{NO})$, superoxide anion $\left(\mathrm{O}_{2}{ }^{-}\right)$, peroxynitrite $\left(\mathrm{ONOO}^{-}\right)$, singlet oxygen $\left({ }^{1} \mathrm{O}_{2}\right)$, hypochlorous acid $(\mathrm{HOCl})$, iron chelating and inhibition of TBARS in a dose-dependent manner. The activity maybe related to the presence and concentration of secondary metabolites present in N.laevis leaf extract.

\section{Methods}

Collection and identification of plant materials

Fresh matured leaves of $N$. laevis were harvested from farms in the Department of Forestry and Environmental
Management, Michael Okpara University of Agriculture, Umudike Nigeria (Latitude $05^{0} 29^{1} \mathrm{~N}$ to $05^{0} 42^{1}$, Longitude $07^{0} 24^{1} \mathrm{E}$ to $\left.07^{0} 33^{1}\right)$. The matured leaves were identified and confirmed by experts of the Department of Forestry, College of Natural Resources and Environmental Management, Michael Okpara, University of Agriculture Umudike, Nigeria. A voucher specimen with the number Ibeh 2011-23 was deposited in the University herbarium for future reference.

\section{Sample preparation}

The leaves of N.laevis were air-dried at room temperature and pulverized into a uniform material using a ThomasWilley mini-milling machine (model 4, 3375-e25). Plant extraction (300 g of pulverized material) was done with $80 \%$ ethanol at $70^{\circ} \mathrm{C}$ by continuous percolation using Soxhlet extractor for 24 hours. The resulting extract was concentrated at $40^{\circ} \mathrm{C}$ in a rotary evaporator to yield a dark green mass of weight $30.3 \mathrm{~g}$ (9.93\%). The obtained crude extract was packed ascetically in airtight plastic containers and stored at $4^{\circ} \mathrm{C}$ until required.

The percentage yield of the extract was calculated using the formula:

$$
\% \text { Yield }=\frac{\text { weight of the extract }}{\text { weight of plant material }} \times \frac{100}{1} .
$$

\section{Phytochemical determination of the metabolites}

For initial phytochemical detection of major metabolites of $N$. laevis thin-layer chromatography (TLC) on silica gel $60 \mathrm{~F}_{254}$ with layer thickness $0.25 \mathrm{~mm}$ (Merck, Darmstadt, Germany) was used after dissolving the extract (2 mg) in $2 \mathrm{ml}$ ethanol. The plates were developed, then left to dry for about $10 \mathrm{~min}$ before they were viewed under UV fluorescence light at 254 and $366 \mathrm{~nm}$. Spraying was done with the required detection reagent to determine the compounds present. For flavonoids, TLC was developed in n-butanol/acetic acid/water (4:1:5), then spots were visualized with $1 \% \mathrm{AlCl}_{3}$ solution in methanol under UV light (366 nm) (Ce 3041 Buck Scientific, UK). Alkaloids, saponins, tannins, anthraquinones, flavonoids, terpenoids, steroids and cardiac glycosides were all identified based on standard methods [26-28]. Quantitative determination was carried out by procedures previously described [29-31]. The concentration of vitamins A, E and $\mathrm{C}$ content of $N$. laevis was estimated using Barakat method [32] for vitamin $C$ and Kirk and Sauya [33] for vitamins $\mathrm{A}$ and $\mathrm{E}$.

\section{Assessment of inhibition of lipid peroxidation}

A modified version of the thiobarbituric acid reactive substances (TBARS) assay was used to assess the extent of lipid peroxides formed using egg yolk homogenate as 
lipid-rich media [34]. Egg homogenate $(0.5 \mathrm{ml}, 10 \%$ in distilled water $\mathrm{v} / \mathrm{v}$ ) was added to $0.1 \mathrm{ml}$ of extract and the volume made up to $1 \mathrm{ml}$ with distilled water. A volume of $0.05 \mathrm{ml}$ of $0.07 \mathrm{M} \mathrm{FeSO}_{4}$ was added to the above mixture and further incubated for $30 \mathrm{~min}$, to induce lipid oxidation. Then $1.5 \mathrm{ml}$ of $20 \%$ acetic acid (pH 3.5), $1.5 \mathrm{ml}$ of $0.8 \% \mathrm{w} / \mathrm{v}$ TBA prepared in $1.1 \% \mathrm{w} / \mathrm{v}$ sodium duodecyl sulphate and $0.05 \mathrm{ml}$ of $20 \% \mathrm{w} / \mathrm{v}$ TCA were sequentially added. The resulting mixture was vortexed and heated at $95^{\circ} \mathrm{C}$ for $60 \mathrm{~min}$. After cooling, $5 \mathrm{ml}$ of butan-1-ol was added and the mixture centrifuged at $3000 \mathrm{rpm}$ for $10 \mathrm{~min}$ (Ultra-8 digital CR Scientific, Koningsweg, Netherlands). The absorbance of the organic upper layer was measured at $532 \mathrm{~nm}$ and converted to percentage inhibition using the formula: Varying concentrations (10 to $400 \mu \mathrm{g} / \mathrm{ml}$ ) of the extract was used for all free radical scavenging (LPO,FRAP, $\mathrm{ONOO}^{-}, \mathrm{HOCl},{ }^{1} \mathrm{O}_{2}, \mathrm{NO}, \mathrm{OH}, \mathrm{Fe}^{2+}$ chelation, DPPH, $\mathrm{O}_{2}^{--}$) analysis. Free radical scavenging potential of $N$. laevis was measured as \% Inhibition and the $\mathrm{IC}_{50}$ values determined in each parameter, comparison were made with corresponding reference compounds. It is imperative to note that the choice of assay standards were made to effectively evaluate the scavenging property of the extract using specific known and well characterized compounds.

$$
\begin{aligned}
& \text { Inhibition of Lipid Peroxidation(\%) } \\
& \quad=(1-\mathrm{E} / \mathrm{C}) \mathrm{X} 100
\end{aligned}
$$

Where $\mathrm{C}=$ absorbance of fully oxidized control and $\mathrm{E}=$ absorbance in the presence of extract.

\section{Ferric reducing potential assay}

The reductive potential (ferric reducing antioxidant power; FRAP) of $N$. laevis was determined based on the chemical reduction of $\mathrm{Fe}^{3+}$ to $\mathrm{Fe}^{2+}$ [35]. Briefly, $50 \mu \mathrm{l}$ of the extract was added to $1.5 \mathrm{ml}$ of freshly prepared and pre-warmed $\left(37^{\circ} \mathrm{C}\right)$ FRAP reagent $(300 \mathrm{mM}$ acetate buffer, $\mathrm{pH}=3.6,10 \mathrm{mM}$ tripyridyl-s-triazine (TPTZ) in $40 \mathrm{mM}$ $\mathrm{HCl}$ and $20 \mathrm{mM} \mathrm{FeCl} 3.6 \mathrm{H} 2 \mathrm{O}$ in the ratio of 10:1:1) and incubated at $37^{\circ} \mathrm{C}$ for $10 \mathrm{~min}$. The absorbance of the sample was read against reagent blank ( $1.5 \mathrm{ml}$ FRAP reagent and $50 \mu \mathrm{l}$ distilled water, [MI]) at $593 \mathrm{~nm}$. Standard solutions of $\mathrm{Fe} 2+$ in the range of 100 to $1000 \mathrm{mM}$ were prepared from ferrous sulphate $(\mathrm{FeSO} 4.7 \mathrm{H} 2 \mathrm{O})$ using distilled water. Thus at low $\mathrm{pH}$, the reduction of ferric tri (2-pyridyl)-1, 3, 5-triazine (Fe III TPTZ) complex to ferrous form (FRAP value) was measured by monitoring the change in absorption at $593 \mathrm{~nm}$. Absorbance (A) readings were taken after $0.5 \mathrm{~s}$ and every $15 \mathrm{~s}$ thereafter during the monitoring period. The change in absorbance $\left(\Delta \mathrm{A}_{593 \mathrm{~nm}}\right)$ between the final reading selected and the M1 reading was calculated for each sample and related to $\left(\Delta \mathrm{A}_{593 \mathrm{~nm}}\right)$ of a $\mathrm{Fe}^{\mathrm{II}}$ standard solution tested in parallel. The reaction was monitored for up to $8 \mathrm{~min}$ but the 4-min readings were selected for calculation of FRAP values. The final result was expressed as concentration of antioxidant having a ferric reducing ability equivalent to that of $1 \mathrm{mmol} / \mathrm{L}$ FeSO4. The calculation was done by:

$$
\begin{aligned}
\operatorname{FRAP}(\mathrm{mM})= & \frac{\left(\Delta \mathrm{A}_{593 \mathrm{~nm}} \text { of sample from } 0-4 \mathrm{~min}\right)}{\left(\Delta \mathrm{A}_{593 \mathrm{~nm}} \text { of standard from } 0 \text { to } 4 \mathrm{~min}\right)} \\
& \times \text { FRAP value of standard }(1000 \mathrm{mM})
\end{aligned}
$$

\section{DPPH based free radical scavenging activity}

DPPH radical scavenging activity was detected for antioxidant activity by thin layer chromatography (TLC) screening through spotting a concentrated ethanolic solution of the extract on silica gel plates. The plates were developed in ethanol: ethyl acetate (2:1) then air-dried and sprayed with $0.2 \% \mathrm{w} / \mathrm{v}$ DPPH spray. The presence of yellow spots were detected. Radical scavenging activity of extracts was measured according to the DPPH spectrophotometric method [36] using vitamin C (Emzor Pharmaceutical Industries, Nigeria) as a reference antioxidant. Ethanol $(1.0 \mathrm{ml})$ plus extract solution $(2.5 \mathrm{ml})$ was used as blank while $1 \mathrm{ml}$ of $0.3 \mathrm{~mm}$ DPPH plus ethanol $(2.5 \mathrm{ml})$ was used as a negative control. The free radical scavenging properties of the extracts against 2 , 2-diphenyl-1-picryl hydrazyl (DPPH) radical were measured at $518 \mathrm{~nm}$, as an index of their antioxidant activity. $\mathrm{IC}_{50}$ values (the concentration of extracts required to scavenge $50 \%$ of DPPH free radicals) were also calculated. The absorbance (abs) of the resulting mixture measured at $518 \mathrm{~nm}$ was converted to percentage antioxidant activity (AA \%) and thus calculated by the equation:

$$
\mathrm{AA} \%=[100-((\mathrm{ABS} \text { sample }-\mathrm{ABSblank}) \times 100)] / \text { ABScontrol }
$$

\section{Superoxide radical scavenging activity}

Measurement of superoxide radical scavenging capacity of $N$. laevis extracts was done using a previously reported method [37] described by Fontana et al. The reaction mixture $(1 \mathrm{ml})$ contained phosphate buffer (20 mM, pH 7.4), NADH (73 $\mu \mathrm{M})$, nitroblue tetrazolium (NBT) solution $(50 \mu \mathrm{M})$, Phenazine methosulphate (PMS) solution $(15 \mu \mathrm{M})$ and various concentration of the plant extract as described elsewhere. The PMS/NADH system generates superoxide radicals, which reduce NBT to a purple formazan. This was incubated at $25^{\circ} \mathrm{C}$ for 5 mins and absorbance measured at $562 \mathrm{~nm}$ against the ethanol blank to determine the quantity of formazan. Thus the assay of SOD is based on the inhibition of the formation of 
NADH-phenazine methosulphate-nitroblue tetrazolium formazan. Quercetin was used as a standard and the percentage inhibition of superoxide anion generation was calculated as previously described in equation 3 .

\section{Nitric oxide radical scavenging assay}

Ebrahimzadeh et al. [38] procedure was adopted to determine the scavenging activity of the plant extracts against nitric oxide radical. Nitric oxide was generated from sodium nitroprusside and measured by the Greiss reaction. Curcumin was used as a standard. Curcumin inhibits induction of nitric oxide synthase and is a naturally occurring direct scavenger of nitric oxide. It reduces the amount of nitrite formed between oxygen and nitric oxide generated from sodium nitroprusside. The absorbance was measured at $596 \mathrm{~nm}$ and the percentage antioxidant activity calculated using the formula in equation 3 .

\section{Hydroxyl radical scavenging assay}

The scavenging activity of the extract against hydroxyl radical was measured using the deoxyribose test-tube method [39] with minor changes. All solutions used was freshly prepared; $200 \mu \mathrm{L}$ of $2.8 \mathrm{mM}$ 2-deoxy-2-ribose, $5 \mu \mathrm{L}$ of $N$. laevis leaf extract, $400 \mu \mathrm{L}$ of $200 \mathrm{mM} \mathrm{FeCl}, 1.04 \mathrm{mM}$ EDTA, $200 \mu \mathrm{L} \mathrm{H}_{2} \mathrm{O}_{2}(1.0 \mathrm{mM}), 200 \mu \mathrm{L}$ ascorbic acid $(1.0 \mathrm{mM})$ and various concentrations $(10-400 \mu \mathrm{g} / \mathrm{ml})$ of the plant extract was mixed to form a reaction mixture. The mixture was incubated for 1 hour at $37^{\circ} \mathrm{C}$. The extent of deoxyribose degradation was measured by TBA reaction. TCA ( $1.5 \mathrm{ml}$ of $2.8 \%$ TCA) was added and kept for 20 mins. The solution was incubated at $90^{\circ} \mathrm{C}$ for $15 \mathrm{~min}$ to develop the colour. Afterwards, the solution was cooled and the absorbance measured at $532 \mathrm{~nm}$ against an appropriate blank solution Mannitol, a classical $\cdot \mathrm{OH}$ scavenger was used as a positive control. The percentage antioxidant activity was calculated using the formula described in equation 3.

\section{Peroxynitrite scavenging}

Peroxynitrite $\left(\mathrm{ONOO}^{-}\right)$was synthesized as described by previous methods [40]. An acidic solution $(0.6 \mathrm{M} \mathrm{HCl})$ of $5 \mathrm{ml} \mathrm{H}_{2} \mathrm{O}_{2}(0.7 \mathrm{M})$ was mixed with $5 \mathrm{ml} 0.6 \mathrm{M} \mathrm{KNO}_{2}$ on an ice bath for one second and $5 \mathrm{ml}$ of ice-cold $1.2 \mathrm{M}$ $\mathrm{NaOH}$ was added. Excess $\mathrm{H}_{2} \mathrm{O}_{2}$ was removed by treatment with granular $\mathrm{MnO}_{2}$ prewashed with $1.2 \mathrm{M} \mathrm{NaOH}$ and the reaction mixture was left overnight at $-20^{\circ} \mathrm{C}$. Collection of peroxynitrite solution was achieved through the top of the frozen mixture and the concentration measured spectrophotometrically at $302 \mathrm{~nm}\left(\varepsilon=1670 \mathrm{M}^{-1} \mathrm{~cm}^{-1}\right)$. The peroxynitrite scavenging activity was determined by Evans Blue bleaching assay [41] with slight modification. The reaction mixture contained $50 \mathrm{mM}$ phosphate buffer (pH 7.4), $0.1 \mathrm{mM}$ DTPA, $90 \mathrm{mM} \mathrm{NaCl}, 5 \mathrm{mM} \mathrm{KCl}$, $12.5 \mu \mathrm{M}$ Evans Blue, various concentrations of the plant extract $(10-400 \mu \mathrm{g} / \mathrm{ml})$ and $1 \mathrm{mM}$ peroxynitrite in a final volume of $1 \mathrm{ml}$. The absorbance was measured at $611 \mathrm{~nm}$ after $30 \mathrm{~min}$ incubation at $25^{\circ} \mathrm{C}$ for. The percentage scavenging of $\mathrm{ONOO}^{-}$was calculated by comparing the results of the test and blank samples. Gallic acid was used as the standard.

\section{Singlet oxygen scavenger}

Production of singlet oxygen $\left({ }^{1} \mathrm{O}_{2}\right)$ was achieved by monitoring $\mathrm{N}, \mathrm{N}$-dimethyl-4-nitrosoaniline (RNO) bleaching, using a previously reported method $[42,43]$. Singlet oxygen was generated by a reaction between $\mathrm{NaOCl}$ and $\mathrm{H}_{2} \mathrm{O}_{2}$ and the bleaching of RNO monitored at $440 \mathrm{~nm}$. The reaction mixture contained $45 \mathrm{mM}$ phosphate buffer (pH 7.1), $50 \mathrm{mM} \mathrm{NaOCl}, 50 \mathrm{mM} \mathrm{H}_{2} \mathrm{O}_{2}, 50 \mathrm{mM}$ histidine, $10 \mu \mathrm{M}$ RNO and various concentrations $(10-400 \mu \mathrm{g} / \mathrm{ml})$ of the plant extract in a final volume of $2 \mathrm{ml}$. It was incubated at $30^{\circ} \mathrm{C}$ for $40 \mathrm{~min}$ and the decrease in RNO absorbance was measured at $440 \mathrm{~nm}$. The scavenging activity of sample was compared with that of lipoic acid, used as a standard compound.

\section{Hypochlorous acid scavenging}

Pedraza-Chaverrí et al. [44] description of hypochlorous acid scavenging activity was adopted with minor modification to determine the hypochlorous acid scavenging activity of N.laevis. Hypochlorous acid $(\mathrm{HOCl})$ was prepared immediately before the experiment by adjusting the $\mathrm{pH}$ of a $10 \%(\mathrm{v} / \mathrm{v})$ solution of $\mathrm{NaOCl}$ to 6.2 with $0.6 \mathrm{M} \mathrm{H}_{2} \mathrm{SO}_{4}$ and the concentration of $\mathrm{HOCl}$ was determined by measuring the absorbance at $235 \mathrm{~nm}$ using the molar extinction coefficient of $100 \mathrm{M}^{-1} \mathrm{~cm}^{-1}$. The scavenging activity was evaluated by determining the decrease in absorbance of catalase at $404 \mathrm{~nm}$. The reaction mixture final volume $(1 \mathrm{ml})$ contained $50 \mathrm{mM}$ phosphate buffer $(\mathrm{pH} 6.8)$, catalase $(7.2 \mu \mathrm{M}), \mathrm{HOCl}(8.4 \mathrm{mM})$ and increasing concentrations $(10-400 \mu \mathrm{g} / \mathrm{ml})$ of plant extract. The assay mixture was incubated at $25^{\circ} \mathrm{C}$ for $20 \mathrm{~min}$ and the absorbance measured against an appropriate blank. Ascorbic acid, a potent $\mathrm{HOCl}$ scavenger, was used as a standard.

\section{Chelation power on ferrous $\left(\mathrm{Fe}^{2+}\right)$ ions}

The ferrous ion chelating activity of the extract was evaluated in vitro as previously reported [45] with minor alterations. The reaction was carried out in HEPES buffer (20 mM, pH 7.2).Various concentrations (10-400 $\mu \mathrm{g} / \mathrm{ml})$ of the plant extract was added to a solution of $2 \mathrm{mM} \mathrm{FeCl}$ $2(0.05 \mathrm{ml})$. The reaction was initiated by the addition of $5 \mathrm{mM}$ ferrozine $(0.2 \mathrm{ml})$ and the mixtures was then shaken vigorously and incubated at room temperature for $20 \mathrm{~min}$. The absorbance of the solution was measured spectrophotometrically at $562 \mathrm{~nm}$. The percentage inhibition of ferrozine- $\mathrm{Fe}^{2}+$ complex formation (ferrous ion chelating ability) was calculated as [(A0 - A1/As)/A0] 
$\mathrm{x} 100$, where $\mathrm{A} 0$ is the absorbance of the control, and A1 is the absorbance of the plant extract and As the absorbance of a standard solution. EDTA was used as a standard.

\section{Statistical analysis}

The statistical analysis was done by one-way analysis of variance (ANOVA) using spss ${ }^{\circ}$ version 18 . The differences between the means were tested using posthoc LSD. A $p$-value of $\mathrm{p}<0.05$ was considered to be statistically significant and result presented as mean \pm standard deviation. All assays were done in sextuplicate. The $\mathrm{IC}_{50}$ values were calculated by the formula $\mathrm{Y}=100^{*} \mathrm{~A} 1 /(\mathrm{X}+\mathrm{A} 1)$, where $\mathrm{A} 1=\mathrm{IC}_{50}$, $\mathrm{Y}=$ response $(\mathrm{Y}=100 \%$ when $\mathrm{X}=0), \mathrm{X}=$ inhibitory concentration. The $\mathrm{IC}_{50}$ values were compared by paired $t$ tests and the antioxidant activity expressed in terms of $\mathrm{IC}_{50}(\mu \mathrm{g} / \mathrm{ml}$ concentration required to inhibit the radical formation by $50 \%$ ).

\section{Ethical approval}

All authors hereby declare that all experiments have been examined and approved by the appropriate ethics committee and have therefore been performed in accordance with the ethical standards laid down in the 1964 Declaration of Helsinki and Michael Okpara University, Umudike, Nigeria.

\section{Competing interests}

The authors declare that they have no competing interests.

\section{Authors' contributions}

This work was carried out in collaboration between all authors. Author IBO conceptualized and designed the work, interpretation of results. Laboratory analysis and drafting of the original manuscripts and final approval of the version. HJB; involved in result interpretation and laboratory analysis. Critical revision of draft article for suitability and intellectual content and final approval of the version. All authors read and approved the final manuscript.

\section{Author details}

'Bioresources Development Centre Odi, Bayelsa, National Biotechnology Development Agency, Abuja, Nigeria. ${ }^{2}$ Department of Biochemistry, College of Natural and Applied Sciences, Michael Okpara University of Agriculture Umudike, Umudike, Nigeria. ${ }^{3}$ National Biotechnology Development Agency, Abuja, Nigeria.

Received: 4 September 2014 Accepted: 23 February 2015

Published online: 14 March 2015

\section{References}

1. Farombi EO. African indigenous plants with chemotherapeutic potentials and biotechnological plants with production of bioactive prophylactic agents. Afr J Biotechnol. 2003;2(12):662-7.

2. Bouayed J, Djilani A, Rammal H, Dicko A, Younos C, Soulimani R. Quantitative evaluation of the antioxidant properties of Catha edulis. J Life Sci. 2008:2:7-14

3. Hutchinson J, Dalziel JM. Flora of West Tropical Africa, vol. II. London, S.W.I. Crown Agents for Oversea Government and Adminstration 4, Millbank; 1963. p. 435-6.

4. Arbonnier M. Trees, Shrubs and Lianas of West African Dry Zones. Cote d'Ivorie: CIRAD, Margraf Publishers GMBH MNHN; 2004. p. 194

5. Lewis WH, Manony PFE. Medical Botany: Plants Affecting Man's Health. New York, USA: John Wiley and Sons; 1977. p. 240.
6. Tor-anyin TA, Sha'ato R, Oluma HOA. Ethnobotanical Survey of antimalarial medicinal plants among the Tiv people of Nigeria. J Herbs Spices Med Plants. 2003;10(3):61-74.

7. Burkill HM. The useful Plants of West Tropical Africa, (Families A-D), vol. 1 2nd ed. Kew, UK: Royal Botanic Gardens; 1985. p. 10. ISBN 094764301X

8. Gbeassor M, Kedjagni AY, Koumagbo K, De Souza C, Agbo K, Aklikokou K, et al. In vitro antimalaria activity of six medicinal plants. Phytother Res. 2006;4(3):115-7.

9. Eyong KO, Folefoc GN, Kuete V, Beng VP, Krohn K, Hussain H, et al. Newbouldia quinine A. A napthoquinone-anthraquinone ether coupled pigment, as a potential antimicrobial and antimalaria agent from Newbouldia laevis. Phtochemistry. 2006;67(6):605-9.

10. Ogunlana EO, Ramstad E. Investigations into the antibacterial activities of local plants. Planta Med. 1975;27:534-60.

11. Ejele AE, Duru IA, Ogukwe CE, Iwu IC. Phytochemistry and antimicrobial potential of basic metabolites of piper umbellatum, piper guineense, Ocimum gratissimium and newbouldia laevis extracts. J Emerg Trends Eng Appl Sci (JETEAS). 2012;3(2):309-14.

12. Iwu MM. Handbook of African Medicinal Plants. London: CRC Press, Inc: 2000. p. 19.

13. Oliver-Bever B. Medicinal plants in Tropical West Africa. London: Cambridge University Press; 1986. p. 117-8. 168.

14. Germann K, Kaloga M, Ferreira D, Marais JP, Kolodziej H. Newbouldioside A-C Phenylethananoid Glycosides from the Stembark of Newbouldia leavis. Phytochemistry. 2006;67(8):805-11.

15. Anaduaka EG, Ogugua VN, Egba SI, Apeh VO. Investigation of some important phytochemical, nutritional properties and toxicological potentials of ethanol extracts of Newbouldia laevis leaf and stem. Afr J Biotechnol. 2013;12(40):5941-9.

16. Akerele JO, Ayinde BA, Ngiagah J. Comparative phytochemical and antimicrobial activities of the leaf and root bark of Newbouldia laevis seem (bignoniaceae) on some clinically isolated bacterial organisms. Niger J Pharm Sci. 2011;10(2):8-14.

17. Usman H, Osuji JC. Phytochemical and in-vitro antimicrobial assay of the leaf extract of Newbouldia laevis. Afr J Trad CAM. 2007:4(4):476-80

18. Kolawole OT, Akanji MA. Effects of extracts of leaves of Newbouldia laevis on the activities of some enzymes of hepatic glucose metabolism in diabetic rats. Afr J Biotechnol. 2014;13(22):2273-81.

19. Miller A. Antioxidant flavonoids: structure, function and clinical usage. Altern Med Rev. 1996;1 (2):103-11.

20. Niki E, Noguchi N, Tsuchihashi H, Naohiro G. Interaction among vitamin C, vitamin E, and 13-carotene13. Am J Clin Nutr. 1995;62(suppl):I322S-6.

21. Mayakrishnan V, Veluswamy S, Sundaram KS, Kannappan P, Abdullah N. Free radical scavenging potential of Lagenaria siceraria (Molina) Standl fruits extract. Asian Pac J Trop Med. 2013;6(1):20-6.

22. Ogulana $\mathrm{OE}$, Ogunlana $\mathrm{OO}$. Invitro assessment of antioxidant activity of Newbouldia laevis. J Med Plant Res. 2008;2(8):176-9.

23. Ogunlana $\mathrm{OE}$, Ogunlana $\mathrm{OO}$, Farombi $\mathrm{OE}$. Assessment of the scavenging activity of crude methanolic stem bark extract of Newbouldia Laevis on selected free radicals. Adv Nat Appl Sci. 2008;2(3):249-54.

24. Robak J, Gryglewski IR. Flavonoids are scavengers of superoxide anions. Biochem Pharmacol. 1988:37:837-41.

25. Balavoine GG, Geletti YV. Peroxynitrite scavenging by different antioxidants. Part 1: convenient study. Nitric Oxide. 1999;3:40-54

26. Harborne JB. Phytochemical Methods; A Guide to Modern Techniques of Plant Analysis. 2nd ed. London: Chapman and Hall; 1973. p. 49-279.

27. Harborne JB. Phytochemical Methods; A Guide to Modern Techniques of Plant Analysis. 2nd ed. London: Chapman and Hall; 1984. p. 4-16.

28. Trease GE, Evans WC. A Text Book of Pharmacognosy. Oxoford, UK: Elsb/Bailliere Tindal; 1987. p. 1055.

29. Trease GE, Evans WC. Pharmacognosy. 4th ed. USA: WB.Sounders; 1996. p. 243-83.

30. Sofowara A. Medical Plants and Traditional Medicine in Africa. Rep. Ibadan: Spectrum books LTD; 2006. p. 150.

31. Harbone JB. Methods of Extraction and Isolation. In: Phytochemical Methods. 3rd ed. London: Chapman and Hall; 1998. p. 42-98.

32. Barakat MZ, Shahab SK, Darwin N, Zahemy El. Determination of ascorbic acid from plants. Anal Biochem. 1993;53:225-45.

33. Kirk RS, Sawyer R. Pearson's Chemical Analysis of Foods. 9th ed. Harlow, UK: Longman Scientific and Technical; 1991. p. 25.

34. Roberto G, Baratta MT. Antioxidant activity of selected essential oil components in two lipid model system. Food Chem. 2000;69(2):167-74. 
35. Benzie FF, Strain JJ. Ferric reducing/antioxidant power assay: direct measure of total antioxidant activity of biological fluids and modified version for simultaneous measurement of total antioxidant power and ascorbic acid concentration. Methods Enzymol. 1999;299:15-23.

36. Mensor LI, Menezes FS, Leitao GG, Reis AS, Santos TC, Coube CS, et al. Screening of Brazilian plant extracts for antioxidant activity by the use of DPPH free radical method. Phytother Res. 2001;15:127-30.

37. Fontana M, Mosca L, Rosei MA. Interaction of enkephalines with oxyradicals. Biochem Pharmacol. 2001;61:1253-7.

38. Ebrahimzadeh MA, Pourmorad F, Hafezi S. Antioxidant Activities of Iranian Corn Silk. Turkish J Biol. 2008;32:43-9.

39. Halliwell B, Gutteridge J, Aruoma OL. The deoxyribose method: a simple test-tube assay for determination of rate constants for reactions of hydroxyl radicals. Anal Biochem. 1987;165(1):215-9.

40. Beckman JS, Chen H, Ischiropulos H, Crow JP. Oxidative chemistry of peroxynitrite. Methods Enzymol. 1994;233:229-40.

41. Bailly F, Zoete V, Vamecq J, Catteu JP, Bernier JL. Antioxidant actions of ovothiol-derived 4-mercaptoimidazoles: glutathione peroxidase activity and protection against peroxynitrite-induced damage. FEBS Lett. 2000;486:19-22.

42. Chakraborty N, Tripathy BC. Involvement of singlet oxygen in 5aminolevulinic acid-induced photodynamic damage of cucumber (Cucumbis sativus L.) chloroplasts. Plant Physiol. 1992;98:7-11.

43. Pedraza-Chaverrí J, Barrera D, Maldonado PD, Chirino Y, Macías-Ruvalcaba NA, Medina-Campos ON, et al. S-allylmercaptocysteine scavenges hydroxyl radical and singlet oxygen in vitro and attenuates gentamicininduced oxidative and nitrosative stress and renal damage in vivo. BMC Clin Pharmacol. 2004;4:5.

44. Pedraza-Chaverrí J, Arriaga-Noblecía G, Medina-Campos ON. Hypochlorous acid scavenging capacity of garlic. Phytother Res. 2007;21:884-8.

45. Haro-Vicente JF, Martinez-Gracia C, Ros G. Optimization of in vitro measurement of available iron from different fortificants in citric fruit juices. Food Chem. 2006;98:639-48.

\section{Submit your next manuscript to BioMed Central and take full advantage of:}

- Convenient online submission

- Thorough peer review

- No space constraints or color figure charges

- Immediate publication on acceptance

- Inclusion in PubMed, CAS, Scopus and Google Scholar

- Research which is freely available for redistribution 